\title{
Correction to: One-repetition submaximal protocol to measure knee extensor muscle strength among older adults with and without sarcopenia: a validation study
}

Pedro Pugliesi Abdalla ${ }^{1 *}$, Anderson dos Santos Carvalho ${ }^{2}$, André Pereira dos Santos', Ana Claudia Rossini Venturini ${ }^{1}$, Thiago Cândido Alves' ${ }^{1}$, Jorge Mota ${ }^{3}$ and Dalmo Roberto Lopes Machado ${ }^{1,4}$

Correction to: BMC Sports Sci Med Rehabil (2020) 12:29 https://doi.org/10.1186/s13102-020-00178-9

Following publication of the original article [1], the authors identified an error in the author name of Anderson dos Santos Carvalho.

The incorrect author name is: Andesron dos Santos Carvalho

The correct author name is: Anderson dos Santos Carvalho

The author group has been updated above and the original article [1] has been corrected.

\footnotetext{
Author details

'College of Nursing of the University of Sao Paulo at Ribeirao Preto (EERP/ USP), Avenida dos Bandeirantes, 3900, Ribeirão Preto, SP 14040-902, Brazil. ${ }^{2}$ Paulista University, Physical Education, Avenida Presidente Juscelino Kubitschek de Oliveira, w/ no, São José do Rio Preto, SP 15092-415, Brazil. ${ }^{3}$ Center for Research in Physical Activity, Health and Leisure (CIAFEL), University of Porto, Rua Dr. Plácido Costa, 91, 4200-450 Porto, Portugal. ${ }^{4}$ School of Physical Education and Sport of Ribeirao Preto at the University of Sao Paulo (EEFERP/USP), Avenida dos Bandeirantes, 3900, Ribeirão Preto, SP 14040-900, Brazil.
}

Published online: 26 May 2020

\section{Reference}

1. Abdalla PP, Carvalho AA, dos Santos AP, et al. One-repetition submaximal protocol to measure knee extensor muscle strength among older adults with and without sarcopenia: a validation study. BMC Sports Sci Med Rehabil. 2020;12:29 https://doi.org/10.1186/s13102-020-00178-9.

The original article can be found online at https://doi.org/10.1186/s13102020-00178-9.

*Correspondence: pedroabdalla11@gmail.com

${ }^{1}$ College of Nursing of the University of Sao Paulo at Ribeirao Preto (EERP/

USP), Avenida dos Bandeirantes, 3900, Ribeirão Preto, SP 14040-902, Brazil

(c) The Author(s). 2020 Open Access This article is licensed under a Creative Commons Attribution 4.0 International License, which permits use, sharing, adaptation, distribution and reproduction in any medium or format, as long as you give appropriate credit to the original author(s) and the source, provide a link to the Creative Commons licence, and indicate if changes were made. The images or other third party material in this article are included in the article's Creative Commons licence, unless indicated otherwise in a credit line to the material. If material is not included in the article's Creative Commons licence and your intended use is not permitted by statutory regulation or exceeds the permitted use, you will need to obtain permission directly from the copyright holder. To view a copy of this licence, visit http://creativecommons.org/licenses/by/4.0/ The Creative Commons Public Domain Dedication waiver (http://creativecommons.org/publicdomain/zero/1.0/) applies to the data made available in this article, unless otherwise stated in a credit line to the data. 